\title{
PENGARUH DIVERSIFIKASI DAN PENGELOLAAN MODAL KERJA TERHADAP NILAI PERUSAHAAN DAN PROFITABILITAS (ROA) PADA PERUSAHAAN MANUFAKTUR SUB SEKTOR MAKANAN DAN MINUMAN YANG TERDAFTAR DI BURSA EFEK INDONESIA (BEI) PERIODE 2016-2018
}

\author{
Mashudiah Sainul Putri \\ Program Studi Magister Manajemen Universitas Tarumanagara \\ mashudiaputri@gmail.com \\ Eko Harry Susanto \\ Program Studi Magister Manajemen Universitas Tarumanagara
}

Masuk : 26-05-2020, revisi : 24-06-2020 diterima untuk diterbitkan : 24-06-2020

\begin{abstract}
This study aims to examine the effect of diversification and working capital management (inventory periods, accounts receivable periods, accounts payable periods, cash conversion cycles) on firm value and profitability of ROA on food and beverage sub-sector manufacturing companies listed on the Indonesia Stock Exchange during the 2016-2018 period. The method used is multiple linear regression test (T-test and F-test) using Eviews 8.0. Samples were selected using a purposive sampling method, which consisted of 12 companies that met the criteria and obtained 36 research sample data. The results of this study indicate that the inventory period and the receivable period significantly influence the value of the company, and the inventory period, the receivable period, the debt period and the cash conversion cycle also have a significant effect on the profitability (ROA) of the company.
\end{abstract}

Abstrak : Penelitian ini bertujuan untuk menguji pengaruh diversifikasi dan pengelolaan modal kerja (periode persediaan, periode piutang, periode hutang, siklus konversi kas) terhadap nilai perusahaan dan profitabilitas ROA (Return on Assets) pada perusahaan manufaktur sub sektor makanan dan minuman yang terdaftar di Bursa Efek Indonesia selama periode 20162018. Metode yang digunakan yaitu uji regresi linear berganda (uji-T dan uji-F) dengan menggunaan Eviews 8.0. Sampel diseleksi dengan menggunakan metode purposive sampling, yang terdiri dari 12 perusahaan yang memenuhi kriteria dan diperoleh 36 data sampel penelitian. Hasil penelitian ini menunjukkan bahwa periode persediaan dan periode piutang berpengaruh signifikan terhadap nilai perusahaan, serta periode persediaan, periode piutang, periode hutang dan siklus konversi kas juga berpengaruh signifikan terhadap profitabilitas (ROA) perusahaan.

Keywords : Firm Value, Profitability, Return on Assets (ROA), Inventory Period, Accounts Receivable Period, Account Payable Period, Cash Conversion Cycle

\section{PENDAHULUAN}

Menurut Indarwati (2015) dunia usaha mengalami perkembangan yang menimbulkan persaingan ketat di antara para pelaku usaha. Semakin ketatnya persaingan usaha antar perusahaan manufaktur di Indonesia saat ini membuat perusahaan dituntut berupaya dalam mengembangkan serta mempertahankan usahanya. Indira Maulani Hapsari seorang Ekonom Bank Dunia menilai industri manufaktur di Indonesia yang masih perlu ditingkatkan karena sektor ini masih merupakan elemen penting bagi pertumbuhan ekonomi di Indonesia pasca krisis ekonomi di tahun 1998 (Idntimes.com-05/12/2018).

Perusahaan manufaktur memiliki tujuan jangka pendek dan jangka panjang. Tujuan jangka pendek suatu perusahaan ialah memperoleh laba maksimal dengan sumber daya yang 
tersedia, dalam hal ini berfokus pada profitabilitas perusahaan tersebut. Sedangkan tujuan jangka panjang perusahaan ialah memaksimalkan nilai perusahaan, di mana nilai perusahaan akan menunjukkan kemakmuran pemegang saham. Dalam upaya pencapaian tujuan ini, perusahaan membutuhkan strategi yang tepat. Strategi diversifikasi merupakan salah satu strategi yang dapat diterapkan oleh perusahaan. Adapun tujuan dari strategi ini ialah untuk mempertahankan keunggulan bersaing yang berkesinambungan serta mempertahankan posisi bersaing perusahaan di pasar.

Peningkatan nilai dan profitabilitas perusahaan juga tidak luput dari perhatian pada segi internal perusahaan tersebut. Dalam hal ini mengacu pada pengelolaan modal kerja yang merupakan perencanaan keuangan untuk kebutuhan operasional perusahaan dalam 1 periode. Meskipun modal kerja bersifat jangka pendek dan sering luput dari perhatian, namun pengelolaan modal kerja dengan baik akan membuat perusahaan mampu memenuhi kewajiban jangka pendek maupun jangka panjang. Pada dasarnya pengelolaan modal kerja berfungsi untuk memelihara keseimbangan antara aset lancar dengan kewajiban lancar. Di mana tidak terdapat jumlah modal kerja yang berlebihan atau modal kerja yang menganggur (Mulia, 2014).

\section{Tujuan Penelitian}

Berdasarkan fenomena yang telah dijelaskan di atas, tujuan penelitian ini adalah:

1. Mengetahui pengaruh diversifikasi terhadap nilai perusahaan manufaktur sub sektor makanan dan minuman yang terdaftar di Bursa Efek Indonesia (BEI).

2. Mengetahui pengaruh pengelolaan modal kerja terhadap nilai perusahaan manufaktur sub sektor makanan dan minuman yang terdaftar di Bursa Efek Indonesia (BEI).

3. Mengetahui pengaruh diversifikasi terhadap profitabilitas (ROA) perusahaan manufaktur sub sektor makanan dan minuman yang terdaftar di Bursa Efek Indonesia (BEI).

4. Mengetahui pengaruh pengelolaan modal kerja terhadap profitabilitas (ROA) perusahaan manufaktur sub sektor makanan dan minuman yang terdaftar di Bursa Efek Indonesia (BEI).

5. Mengetahui pengaruh diversifikasi dan pengelolaan modal kerja terhadap nilai perusahaan dan profitabilitas (ROA) perusahaan manufaktur sub sektor makanan dan minuman yang terdaftar di Bursa Efek Indonesia (BEI).

\section{TINJAUAN PUSTAKA}

Nilai perusahaan menjadi dependent variable pertama dalam penelitian ini. Nilai perusahaan merupakan pencerminan dari kinerja perusahaan melalui harga saham yang dibentuk oleh permintaan dan penawaran di pasar modal. Nilai perusahaan merefleksikan penilaian masyarakat terkait suatu perusahaan apabila perusahaan tersebut dijual (Sholikhannisa, 2017). Nilai perusahaan diproksikan dengan Price to Book Value (PBV) yang merupakan hasil perbandingan antara harga saham dengan nilai buku per lembar saham.

Profitabilitas menjadi dependent variable kedua dalam penelitian ini. Menurut Blazkova (2016) profitabilitas digunakan sebagai alat untuk mengukur kinerja keuangan sebuah perusahaan. Indikator pengembalian aset menggambarkan tingkat efektivitas perusahaan dalam mengelola aset untuk menghasilkan laba bagi perusahaan. Untuk itu, profitabilitas dalam penelitian ini diproxykan dengan Return on Assets (ROA). Bongini, Laeven dan Majnoni (2013) mengartikan ROA sebagai rasio keuangan perusahaan yang terkait dengan potensi keuntungan atau juga laba pada tingkat pendapatan, aset dan juga modal saham spesifik.

Diversifikasi sebagai independent variable pertama merupakan kegiatan perusahaan dimana perusahaan tersebut mengembangkan bisnis utamanya ke bisnis lainnya baik yang saling berkaitan maupun yang tidak saling berkaitan (Bhatia \& Thakur, 2018). Proxy untuk mengukur diversifikasi adalah Herfindahl Index yang dihitung berdasarkan distribusi penjualan masing-masing segmen bisnis dari suatu perusahaan.

Pengelolaan modal kerja sebagai independent variable kedua. Pais dan Gama (2015) menyatakan bahwa perusahaan yang memiliki pengelolaan modal kerja yang baik mampu 
bertahan dan berada dalam kondisi yang lebih baik dibandingkan perusahaan yang tidak mengelola modal kerja secara efektif. Dalam penelitian ini modal kerja terdiri dari beberapa elemen, di antaranya :

a. Periode persediaan ialah ukuran dari jumlah rata-rata persediaan yang ada,

b. Periode piutang ialah ukuran arus kas yang dihitung dengan membagi rata-rata piutang dengan penjualan kredit per hari,

c. Periode hutang ialah ukuran dari jumlah rata-rata hari yang diperlukan untuk membayar pemasok dan

d. Siklus konversi kas ialah lama waktu antara pembayaran untuk modal kerja dan penagihan kas dari penjualan modal kerja.

\section{Kerangka Penelitian}

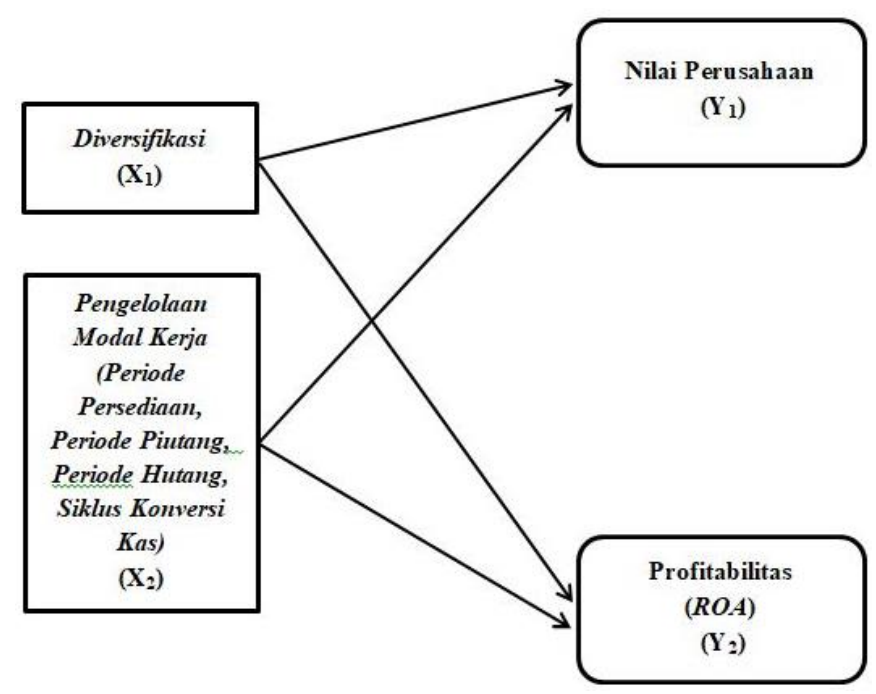

Gambar 1

Kerangka Penelitian

Sehingga hipotesis dalam penelitian ini ialah :

\section{Pengaruh $\mathrm{X}$ terhadap $\mathrm{Y}_{1}$}

$\mathrm{Ho}_{1}$ : Diversifikasi tidak berpengaruh terhadap nilai perusahaan

$\mathrm{Ha}_{1}$ : Diversifikasi berpengaruh terhadap nilai perusahaan

$\mathrm{Ho}_{2} 1$ : Periode persediaan tidak berpengaruh terhadap nilai perusahaan

$\mathrm{Ha}_{2}{ }_{1}$ : Periode persediaan berpengaruh terhadap nilai perusahaan

$\mathrm{Ho}_{2} \_2$ : Periode piutang tidak berpengaruh terhadap nilai perusahaan

$\mathrm{Ha}_{2} 2$ : Periode piutang berpengaruh terhadap nilai perusahaan

$\mathrm{Ho}_{2} 3$ : Periode hutang tidak berpengaruh terhadap nilai perusahaan

$\mathrm{Ha}_{2} 3$ : Periode hutang berpengaruh terhadap nilai perusahaan

$\mathrm{Ho}_{2} 4$ : Siklus konversi kas tidak berpengaruh terhadap nilai perusahaan

$\mathrm{Ha}_{2} 4$ : Siklus konversi kas berpengaruh terhadap nilai perusahaan

\section{Pengaruh $\mathrm{X}$ terhadap $\mathrm{Y}_{2}$}

$\mathrm{Ho}_{1}$ : Diversifikasi tidak berpengaruh terhadap profitabilitas (ROA)

$\mathrm{Ha}_{1} \quad$ : Diverifikasi berpengaruh terhadap profitabilitas (ROA)

$\mathrm{Ho}_{2}{ }_{1}$ : Periode persediaan tidak berpengaruh terhadap profitabilitas (ROA)

$\mathrm{Ha}_{2}{ }_{1}$ : Periode persediaan berpengaruh terhadap profitabilitas (ROA)

$\mathrm{Ho}_{2} 2$ : Periode piutang tidak berpengaruh terhadap profitabilitas (ROA)

$\mathrm{Ha}_{2} \_2$ : Periode piutang berpengaruh terhadap profitabilitas (ROA)

$\mathrm{Ho}_{2} 3$ : Periode hutang tidak berpengaruh terhadap profitabilitas (ROA)

$\mathrm{Ha}_{2} 3$ : Periode hutang berpengaruh terhadap profitabilitas (ROA)

$\mathrm{Ho}_{2} 4$ : Siklus konversi kas tidak berpengaruh terhadap profitabilitas (ROA)

$\mathrm{Ha}_{2} 4$ : Siklus konversi kas berpengaruh terhadap profitabilitas (ROA) 


\section{METODOLOGI PENELITIAN}

Sampel dari penelitian ini ialah perusahaan-perusahaan manufaktur yang terdaftar di Bursa Efek Indonesia selama tahun 2016-2018. Jumlah perusahaan yang menjadi sampel penelitian adalah 12 perusahaan dari 26 perusahaan manufaktur sub sektor makanan dan minuman. Sumber data merupakan data sekunder yang diperoleh dari laporan keuangan, laporan laba-rugi dan laporan harga saham masing-masing perusahaan. Jenis data merupakan data panel dengan pengujian regresi linear berganda menggunakan Eviews 8.0.

Variabel operasional dalam penelitian ini adalah nilai perusahaan yang diproksikan dengan skala rasio yaitu Price to Book Value $(P B V)$ serta profitabilitas yang diproksikan dengan Return on Assets (ROA) sebagai dependent variable. Sedangkan independent variable dalam penelitian ini adalah diversifikasi yang diproksikan dengan Herfindahl Index (HERF) dan pengelolaan modal kerja yang diproksikan dengan periode persediaan, periode piutang, periode hutang dan siklus konversi kas.

\section{ANALISA DAN PEMBAHASAN}

Dari pengujian Chow Test dan Hausman Test diperoleh model terbaik Random Effect. Dilanjutkan dengan pengujian parsial (T-Test) dan pengujian simultan $(F-T e s t)$ dengan tingkat signifikansi $5 \%$ diperoleh hasil sebagai berikut :

Tabel 1 ( $\mathrm{Y}_{1}$ : Nilai Perusahaan)

\begin{tabular}{|c|c|c|c|c|}
\hline Variable & Coefficient & Std. Error & t-Statistic & Prob. \\
\hline $\mathrm{C}$ & 4.969881 & 3.131115 & 1.587256 & 0.1229 \\
\hline $\mathrm{X} 1$ & -4035.292 & 2106.338 & -1.915785 & 0.0650 \\
\hline $\mathrm{X} 2 \_1$ & -0.156432 & 0.049391 & -3.167189 & 0.0064 \\
\hline $\mathrm{X} 2-2$ & -0.159818 & 0.049108 & -3.254411 & 0.0053 \\
\hline $\mathrm{X} 2 \_3$ & 0.141896 & 0.072454 & 1.958420 & 0.0643 \\
\hline $\mathrm{X} 2 \_4$ & 0.142497 & 0.072297 & 1.970984 & 0.0627 \\
\hline \multicolumn{5}{|c|}{ Effects Specification } \\
\hline & & & S.D. & Rho \\
\hline Cross-section randon & & & 6.281472 & 0.6954 \\
\hline Idiosyncratic random & & & 4.157198 & 0.3046 \\
\hline \multicolumn{5}{|c|}{ Weighted Statistics } \\
\hline R-squared & 0.724695 & \multirow{5}{*}{\multicolumn{2}{|c|}{$\begin{array}{l}\text { Mean dependentyar } \\
\text { S.D. dependent yar } \\
\text { Sum squared resid } \\
\text { Durbin-Watson stat }\end{array}$}} & 1.635346 \\
\hline Adiusted R-squared & 0.518217 & & & 3.944124 \\
\hline S.E. of regression & 4.243206 & & & 478.8021 \\
\hline F-statistic & 3.509787 & & & 1.667517 \\
\hline Prob(F-statistic) & 0.004937 & & & \\
\hline
\end{tabular}

Tabel $2\left(\mathrm{Y}_{2}: \mathrm{ROA}\right)$

\begin{tabular}{|c|c|c|c|c|}
\hline Variable & Coefficient & Std. Error & t-Statistic & Prob. \\
\hline $\mathrm{C}$ & 5.626591 & 1.727717 & 3.256663 & 0.0028 \\
\hline $\mathrm{X} 1$ & -390.2966 & 577.7381 & -0.675560 & 0.5045 \\
\hline $\mathrm{X} 2 \_1$ & 0.021734 & 0.009726 & 2.234652 & 0.0330 \\
\hline $\mathrm{x} 2{ }^{-} 2$ & 0.044166 & 0.018948 & 2.330853 & 0.0267 \\
\hline $\mathrm{X} 2 \_3$ & -0.021942 & 0.009783 & -2.242956 & 0.0324 \\
\hline $\mathrm{X} 2{ }_{-}^{-} 4$ & -0.020643 & 0.009672 & -2.134365 & 0.0411 \\
\hline \multicolumn{5}{|c|}{ Effects Specification } \\
\hline & & & S.D. & Rho \\
\hline Cross-section randon & & & 5.056279 & 0.9561 \\
\hline Idiosyncratic random & & & 1.083742 & 0.0439 \\
\hline \multicolumn{5}{|c|}{ Weighted Statistics } \\
\hline R-squared & 0.982870 & \multirow{5}{*}{\multicolumn{2}{|c|}{$\begin{array}{l}\text { Mean dependentyar } \\
\text { S.D. dependent yar } \\
\text { Sum squared resid } \\
\text { Durbin-Watson stat }\end{array}$}} & 0.939156 \\
\hline Adiusted R-squared & 0.968445 & & & 1.135130 \\
\hline S.E. of regression & 1.083742 & & & 36.58851 \\
\hline F-statistic & 68.13633 & & & 1.725283 \\
\hline Prob(F-statistic) & 0.000000 & & & \\
\hline
\end{tabular}

Sumber : diolah peneliti (2020)

\section{Uji T}

Pada Tabel 1 menunjukkan nilai prob. $\mathrm{X}_{1}, \mathrm{X}_{2 \_3}$ dan $\mathrm{X}_{2 \_4}$ masing-masing sebesar 0.0650 , 0.0643 dan 0.0627 lebih besar dari 0.05, sehingga disimpulkan bahwa diversifikasi, periode hutang dan siklus konversi kas tidak berpengaruh signifikan terhadap nilai perusahaan. Sedangkan nilai prob. $\mathrm{X}_{2 \_1}$ dan $\mathrm{X}_{2 \_2}$ masing-masing sebesar 0.0064 dan 0.0053 lebih kecil dari 0.05, sehingga disimpulkan bahwa periode persediaan dan periode piutang berpengaruh signifikan dengan korelasi negatif terhadap nilai perusahaan.

Pada Tabel 2 menunjukkan nilai prob. $\mathrm{X}_{1}$ sebesar 0.5045 lebih besar dari 0.05, sehingga disimpulkan diversifikasi tidak berpengaruh signifikan terhadap profitabilitas (ROA). Sedangkan nilai prob. $\mathrm{X}_{2 \_1}$ dan $\mathrm{X}_{2 \_2}$ masing-masing sebesar 0.0330 dan 0.0267 lebih kecil dari 0.05 , sehingga disimpulkan bahwa periode persediaan dan periode piutang berpengaruh signifikan dengan korelasi positif terhadap profitabilitas (ROA). Untuk nilai prob. $\mathrm{X}_{2 \_3}$ dan $\mathrm{X}_{2 \_}$masing-masing sebesar 0.0324 dan 0.0411 lebih kecil dari 0.05 , sehingga disimpulkan bahwa periode hutang dan siklus konversi kas berpengaruh signifikan dengan korelasi negatif pada profitabilitas (ROA). 


\section{Uji F}

Pada Tabel 1 dan Tabel 2 menunjukkan nilai prob. F-Statistic masing-masing 0.004937 dan 0.000000 lebih kecil dari 0.05 , sehingga disimpulkan bahwa diversifikasi $\left(\mathrm{X}_{1)}\right.$ dan pengelolaan modal kerja $\left(\mathrm{X}_{2}\right)$ yang terdiri dari periode persediaan $\left(\mathrm{X}_{2_{-}}\right)$, periode piutang $\left(\mathrm{X}_{2 \_}\right)$, periode hutang $\left(\mathrm{X}_{2 \_}\right)$dan siklus konversi kas $\left(\mathrm{X}_{2 \_}\right)$berpengaruh secara simultan terhadap nilai perusahaan maupun profitabilitas (ROA).

\section{Koefisien Determinasi}

Pada Tabel 1 menunjukkan nilai Adjusted $R$-squared sebesar 0.518217 yang berarti bahwa diversifikasi $\left(X_{1}\right)$, periode persediaan $\left(X_{2_{-}}\right)$, periode piutang $\left(X_{2_{-} 2}\right)$, periode hutang $\left(\mathrm{X}_{2 \_}\right)$dan siklus konversi kas $\left(\mathrm{X}_{2 \_}\right)$memiliki proporsi pengaruh terhadap profitabilitas nilai perusahaan $\left(\mathrm{Y}_{1}\right)$ sebesar $51.8217 \%$ sedangkan sisanya $48.1783 \%$ dipengaruhi oleh variabel lain yang tidak ada di dalam model regresi.

Pada Tabel 2 menunjukkan nilai Adjusted R-squared sebesar 0.968445 yang berarti bahwa diversifikasi $\left(\mathrm{X}_{1}\right)$, periode persediaan $\left(\mathrm{X}_{2_{-}}\right)$, periode piutang $\left(\mathrm{X}_{2 \_}\right)$, periode hutang $\left(\mathrm{X}_{2 \_}\right)$dan siklus konversi kas $\left(\mathrm{X}_{2 \_}\right)$memiliki proporsi pengaruh terhadap profitabilitas Return on Assets $\left(\mathrm{Y}_{2}\right)$ sebesar $96.8445 \%$ sedangkan sisanya $3.1555 \%$ dipengaruhi oleh variabel lain yang tidak ada di dalam model regresi.

\section{KESIMPULAN DAN SARAN Kesimpulan.}

Dari hasil penelitian disimpulkan bahwa terdapat 2 komponen penting bagi perusahaan yakni nilai perusahaan untuk jangka panjang dan tingkat profitabilitas perusahaan untuk jangka pendek. Bagi perusahaan manufaktur sub sektor makanan dan minuman dalam upaya menjaga atau mempertahankan nilai perusahaannya dapat memfokuskan perhatian utama pada pengelolaan modal kerja khususnya pada elemen periode persediaan dan periode piutang karena pada 2 variabel ini ditemukan pengaruh negatif. Sebaliknya, dalam upaya peningkatan tingkat profitabilitas (ROA) perusahaan manufaktur sub sektor makanan dan minuman memfokuskan perhatian pada pengelolaan modal kerja khususnya pada elemen periode persediaan dan periode piutang karena pada 2 variabel ini ditemukan pengaruh positif. Hal ini berarti jika 2 variabel ini dapat dioptimalkan maka dampaknya akan menguntungkan perusahaan dari sisi Return on Asset. Sedangkan pada elemen periode hutang dan siklus konversi kas memberikan pengaruh negatif yang berarti peningkatan jumlah/nilai dari variabel ini dapat mengakibatkan penurunan pada tingkat profitabilitas (ROA) perusahaan. Variabel diversifikasi pada penelitian ini belum ditemukan pengaruh dan dampaknya terhadap peningkatan atau penurunan nilai perusahaan maupun profitabilitas (ROA) perusahaan manufaktur sub sektor makanan dan minuman.

\section{Saran}

Peneliti menyarankan perusahaan manufaktur sub sektor makanan dan minuman untuk (1) melakukan pertimbangan terkait strategi diversifikasi yang akan diterapkan sebagai cara dalam peningkatan nilai dan profitabilitas perusahaan, (2) perusahaan mengoptimalkan pengelolaan modal kerja perusahaan dengan baik guna mencapai keefisienan biaya dari modal kerja tersebut sehingga tercapai peningkatan produktivitas, (3) diharapkan untuk selalu mempertahankan dan mengupayakan peningkatan nilai perusahaan dengan menjaga tingkat profitabilitas ROA serta memperhatikan faktor-faktor pembentuk aset dan nilai perusahaan sehingga perusahaan dapat memperoleh laba (keuntungan) yang lebih besar dan memiliki kinerja yang baik yang dinilai dari sudut internal maupun eksternal. Selain itu, saran bagi peneliti selanjunya ialah dapat menggunakan periode penelitian yang lebih panjang, meneliti sektor yang lebih luas, menambahkan variabel independen dan variabel dependen, menambahkan variabel mediasi dan moderasi, serta memperhitungkan variabel makro. 


\section{DAFTAR PUSTAKA}

Bhatia, A., \& Thakur, A. (2018). Corporate Diversification and Firm Performance: An Empirical Investigation of Causality. International Journal of Organizational Analysis, 26 (2), 202-225. https://doi.org/10.1108/IJOA-04-2017-1149

Blazkova, I. (2016). Profitability of Czech Food Enterprises in Relation to Their Size. Acta Universitatis Bohemiae Meridionalis, 19 (2). https://doi.org/10.1515/acta-2016-0011

Bongini, P., Laeven, L., \& Majnoni, G. (2013). How Good is The Market at Assessing Bank Fragility? A Horse Race between Different Indicators. Journal of Banking and Finance, 26 (5), 1029-1031. https://doi.org/10.1016/S0378-4266(01)00273-4

Indarwati, P. (2015). Analisis Pengaruh Struktur Kepemilikan terhadap Kinerja Perusahaan Manufaktur. Jurnal Ilmu Manajemen dan Akuntansi Terapan (JIMAT), 6 (1), 104-119.

Mulia, A. (2014). Analisis Pengaruh Kinerja Aparatur terhadap Pelayanan Publik Bagian Perekonomian Kota Makassar (Studi Kasus Dinas Perdagangan Kota Makassar). Jurnal Minds : Manajemen Ide dan Inspirasi, 3 (2).

Pais, M. A., \& Gama, P. M. (2015). Working Capital Management and SME's Profitability: Portuguese Evidence. International Journal of Managerial Finance, 11 (3), 341-358. https://doi.org/10.1108/IJMF-11-2014-0170

Sholikhannisa, N. (2017). Pengaruh Strategi Diversifikasi, Profitabilitas terhadap Nilai Perusahaan dengan Kepemilikan Manajerial sebagai Variabel Moderasi (Studi pada Perusahaan Manufaktur yang Terdaftar di BEI Periode 2016-2017). Journal of Business Economics and Management, 1-25.

http://www.idntimes.com

http://www.idx.co.id. 